\title{
Dietary restrictions in rheumatoid arthritis-what the patient's feel: A questionnaire based study.
}

\author{
Velammal Petchiappan, Preethi Priyadarshini, Nagaprabu VN* \\ DNB Rheumatology, Sakthi Rheumatology Centre Private Ltd., Coimbatore, Tamilnadu, India
}

\begin{abstract}
Background: There is increasing evidence for the role of diet in the etiopathogenesis of Rheumatoid Arthritis (RA) while it is not clear how it modifies the disease activity in view of inconclusive results of various dietary intervention studies. We intend to study the influence of diet on RA patients by a simple questionnaire.

Methods and findings: Descriptive cross-sectional study was carried out among 101 consecutive RA patients with simple questionnaire and analysed whether they had dietary restriction or not and how it affected their symptoms. There were 44 patients who restricted their diet and 57 who did not observe dietary restriction. Of the 44 dietary restrictors, $20(44.5 \%)$ had reported worsening of joint pains after a particular food while 52 out of 57 non dietary restrictors $(91.2 \%)$ did not feel a difference in the joint symptoms with food intake which was statistically significant $(p<0.0001)$. Just like patient reported disease outcome measures which are less complicated and time consuming has emerged as a promising tool in the disease management, this study also observed that majority of our patients are right in restricting their diet based on their joint symptoms.
\end{abstract}

Conclusion: The patient has to decide on their own basis whether or not to restrict a particular food item based on their symptoms instead of imposing a specific dietary pattern until we get more evidence to prove the contrary.

Keywords: Dietary restriction for arthritis, Diet and rheumatoid arthritis, Diet in early rheumatoid arthritis, Diet in established rheumatoid arthritis, Questionnaire for diet in rheumatoid arthritis.

Abbreviations: DMARDS: Disease Modifying Anti-Rheumatic Drugs; RA: Rheumatoid Arthritis.

Accepted on May 26, 2018

\section{Introduction}

Rheumatoid arthritis (RA) is one of the commonest debilitating arthritis which has seen a sea change in the diagnosis and management over the past few decades. While pharmacological therapies receive prime importance in the management plan, non- pharmacological measures are often neglected, but the scenario is changing, and more focus is made on the nonpharmacological intervention measures including diet, exercise and healthy life habits.

The pathogenesis of RA is complex which includes genetic and non -genetic factors. Non-genetic factors account for around $40 \%$ of the risk for RA [1]. Among the non-genetic factors cigarette smoking is a well-established risk factor for the development of inflammatory polyarthritis [2-5]. Diet is another well studied risk factor [6,7]; it can influence the body weight which has a bearing on the individual's mobility; also it can affect the inflammatory process by altering the gut micro flora, anti-oxidant activity. The presence of altered intestinal micro flora is implicated in the pathogenesis as well as the disease progression in RA [8-10]. Diet can have positive and negative impact on the disease. High protein diets is implicated in the disease pathogenesis $[11,12]$ while low protein diets can improve RA related symptoms [13-16]. A very high prevalence of RA is noted in countries with greater consumption of red meat
[17]. Certain food items like fish [18,19], cooked vegetables, and $\beta$ cryptoxanthin found in fruits and vegetables [20-22] have a possible protective effect while increased coffee intake is associated with the greater risk of RA $[23,24]$. Patients with RA were subjected to various dietary interventions to improve or lessen the burden of the disease. Studies done so far to find out the impact of the diet on disease activity and symptoms have shown variable results.

In a study by Proudman et al. [25], consumption of fish rich in omega 3 fatty acids, in combination with conventional Disease Modifying Anti -Rheumatic Drugs (DMARDS) is more likely to achieve remission than DMARDS alone. There are conflicting results with regard to protein intake. Pattison et al. [12] studied the intake of red meat and the occurrence of inflammatory polyarthritis and concluded that increased intake of red meat is associated with higher risk of developing inflammatory polyarthritis, whereas Nurses' Health Study [26] has given contradictory results.

In real life scenario, many patients with RA report that there is increase in their joint symptoms after taking a particular food and they adjust their dietary pattern based on their experience by restricting that particular diet in future and gets benefited by their own dietary manipulation. The question about the influence of diet on the occurrence of arthritis related symptoms remain 
large for the patients. With this background, we intended to study the role of diet in RA patients and its impact on the arthritis related symptoms as perceived by the patients themselves using a simple questionnaire in their own language.

\section{Aim}

To study the influence of diet on the joint related symptoms in patients with Rheumatoid arthritis as perceived by them.

\section{Methodology}

Descriptive study was carried out among 101 consecutive Rheumatoid arthritis patients attending the out-patient services of Rheumatology Department during September 2012-March 2013 in a tertiary care centre, Coimbatore, Southern India. Patients aged more than 17 years of age with a diagnosis of RA as per American College of Rheumatology 2010 criteria and on standard DMARDS (Methotrexate 10 -25 mg/week; Hydroxychloroquine 200-400 mg/day; Leflunomide 10-20 MG/day; Prednisolone $<7.5 \mathrm{mg} /$ day) were included in the study however among them subjects were excluded if other Connective tissue diseases like Systemic lupus erythematosus, Fibromyalgia and Spondyloarthropathies, those who require frequent change in dose of DMARDS and not willing to participate in the study.

The study design was approved by the Institutional Ethics committee. After getting the consent, the participants were given a questionnaire in their local language which includes key details like disease duration, dietary pattern, history regarding co-morbidities and exposure to alternative medicine therapy; their regular diet patterns, whether they are restricting any particular food item; have they felt any change in the joint symptoms (new onset pain or stiffness, involvement of multiple joints) after a particular food intake and if so, they were asked to list down the name of food items which they think is responsible for the change in symptom.

\section{Statistical analysis}

Disease duration was calculated from the time of first symptom occurrence till the date of sampling and categorised as $\leq 6$ months and $>6$ months. Diet restriction was categorised as diet restrictors and non-diet restrictors.

Descriptive statistics were reported using mean with standard deviation for continuous variables and percentages for categorical variables. Independent $t$ test was used to compare the mean age between two groups. Chi-square test was used to test the association between diet restriction and disease duration with other study variables. P value less than $5 \%$ was considered as statistically significant. All the analyses were done using SPSS version 23.0 software.

\section{Results}

The characteristics of the study population are listed in Table 1. There were 85 female patients and 16 were male with ratio of $5.3: 1$. Mean age of the study subjects was $48.3 \pm 11.6$ years. The average disease duration of the study population was 50.2 \pm 65.4 months. When we divided the patient into early with disease duration of $\leq 6$ months and established RA with more than 6 months there were 80 with established disease while 21 had early disease.

Of the 101 patients $40(39.6 \%)$ had been exposed to complementary therapies in the past in the form of Ayurveda, Siddha and Homeopathy. 18 patients had associated co-morbid illness; most commonly reported was Systemic hypertension which was seen in 12 patients and 5 patients had diabetes while one had both Diabetes mellitus and Systemic hypertension. The diet pattern of the patient population is quite variable with 66 of them taking mixed diet (both vegetarian and non-vegetarian) and 35 were lacto-vegetarians.

There were a total of 44 patients $(43.6 \%)$ who were following some kind of dietary restriction which was self-imposed in 5; by relatives and friends in 7 while 32 were advised by their primary care physicians itself. The remaining 57(56.4\%) did mention that they did not follow any dietary restriction.

Of the total 101 patients, only $25(24.8 \%)$ felt there was a change in the joint symptoms on taking particular diet, of this 20 were following diet restriction and the remaining 5 belonged to the non-diet restrictors group. The list of food items which worsened the joint symptoms is mentioned in the Table 2.

\section{Disease duration and diet restriction}

The mean disease duration in the early RA was 4.28 months and in established RA was 62.68 months. Although not statistically significant, the proportion of patients who had been exposed to alternative medicine was more in established RA $(42.5 \%)$ than in early RA (28.6\%).

In the early RA subgroup, seven patients $(33.3 \%)$ had felt a need for diet restriction; the remaining fourteen $(66.7 \%)$ did not have any restriction in the food intake. Eighteen among the early disease group (85.7\%) did not observe any change in their joint symptoms after a particular food while three $(14.3 \%)$ noticed worsening of their symptoms.

Table 1. Characteristics of the study population.

\begin{tabular}{|c|c|c|}
\hline Characteristics & Number & Percentage \\
\hline Age in years & \multicolumn{2}{|c|}{$48.3 \pm 11.6$} \\
\hline $\begin{array}{l}\text { Sex } \\
\text { Female } \\
\text { Male }\end{array}$ & $\begin{array}{l}85 \\
16\end{array}$ & $\begin{array}{l}84.2 \\
15.8\end{array}$ \\
\hline $\begin{array}{l}\text { Duration of disease } \\
\quad<=6 \text { months } \\
\quad>6 \text { months }\end{array}$ & $\begin{array}{l}21 \\
80\end{array}$ & $\begin{array}{l}20.8 \\
79.2\end{array}$ \\
\hline $\begin{array}{c}\text { Alternative medications } \\
\text { Yes } \\
\text { No }\end{array}$ & $\begin{array}{l}40 \\
61\end{array}$ & $\begin{array}{l}39.6 \\
60.4\end{array}$ \\
\hline $\begin{array}{c}\text { Co morbid conditions } \\
\text { Yes } \\
\text { No }\end{array}$ & $\begin{array}{l}18 \\
83\end{array}$ & $\begin{array}{l}17.8 \\
82.2\end{array}$ \\
\hline $\begin{array}{c}\text { Diet Restriction for co-morbid } \\
\text { Yes } \\
\text { No }\end{array}$ & $\begin{array}{c}8 \\
93\end{array}$ & $\begin{array}{c}7.9 \\
92.1\end{array}$ \\
\hline $\begin{array}{c}\text { Diet restriction for Arthritis } \\
\text { Yes } \\
\text { No }\end{array}$ & $\begin{array}{l}44 \\
57\end{array}$ & $\begin{array}{l}43.6 \\
56.4\end{array}$ \\
\hline $\begin{array}{c}\text { Any difference in arthritis } \\
\text { Yes } \\
\text { No }\end{array}$ & $\begin{array}{l}25 \\
76\end{array}$ & $\begin{array}{l}24.8 \\
75.2\end{array}$ \\
\hline $\begin{array}{l}\text { Type of food } \\
\text { Vegetarian } \\
\text { Mixed }\end{array}$ & $\begin{array}{l}35 \\
66\end{array}$ & $\begin{array}{l}34.7 \\
65.3\end{array}$ \\
\hline
\end{tabular}


Table 2. Food items reported to worsen the joint symptoms.

\begin{tabular}{|c|c|c|}
\hline \multicolumn{3}{|c|}{ Chicken, Meat, Raw rice } \\
\hline $\begin{array}{c}\text { Bajji (snack item made of } \\
\text { gram flour deep fried in oil) }\end{array}$ & $\begin{array}{c}\text { Uzhundu vada (snack item } \\
\text { made of Bengal gram flour } \\
\text { deep fried in oil) }\end{array}$ & Lemon pickles \\
\hline Potato & Pumpkin & Unripe banana \\
\hline Curd & Milk & Egg \\
\hline
\end{tabular}

Table 3. Comparison of characteristics by disease duration: Reported as number within parenthesis percentages; $p$ value using chi-square test; ${ }^{*}$ - $p$ value using independent t test.

\begin{tabular}{|c|c|c|c|}
\hline & \multicolumn{2}{|c|}{ Disease Duration } & \multirow[b]{2}{*}{$P$ value } \\
\hline & $\begin{array}{c}\leq 6 \text { months } \\
\mathrm{n}-21\end{array}$ & $\begin{array}{c}>6 \text { months } \\
\mathrm{n}-80\end{array}$ & \\
\hline Age in years & $44.1 \pm 10.6$ & $49.4 \pm 11.8$ & $0.06^{*}$ \\
\hline $\begin{array}{l}\text { Sex } \\
\text { Female } \\
\text { Male }\end{array}$ & $\begin{array}{c}17(81.0) \\
4(19.0)\end{array}$ & $\begin{array}{l}68(85.0) \\
12(15.0)\end{array}$ & 0.65 \\
\hline $\begin{array}{c}\text { Alternative Medications } \\
\text { Yes } \\
\text { No }\end{array}$ & $\begin{array}{c}6(28.6) \\
15(71.4)\end{array}$ & $\begin{array}{l}34(42.5) \\
46(57.5)\end{array}$ & 0.24 \\
\hline $\begin{array}{c}\text { Co morbid conditions } \\
\text { Yes } \\
\text { No }\end{array}$ & $\begin{array}{c}5(23.8) \\
16(76.2)\end{array}$ & $\begin{array}{l}13(16.3) \\
67(83.8)\end{array}$ & 0.32 \\
\hline $\begin{array}{c}\text { Any difference in arthritis } \\
\text { Yes } \\
\text { No }\end{array}$ & $\begin{array}{c}3(14.3) \\
18(85.7)\end{array}$ & $\begin{array}{l}22(27.5) \\
58(72.5)\end{array}$ & 0.21 \\
\hline $\begin{array}{l}\text { Diet restriction } \\
\text { Yes } \\
\text { No }\end{array}$ & $\begin{array}{c}7(33.3) \\
14(66.7)\end{array}$ & $\begin{array}{l}37(46.3) \\
43(53.8)\end{array}$ & 0.28 \\
\hline $\begin{array}{l}\text { Type of food } \\
\text { Veg } \\
\text { Mixed }\end{array}$ & $\begin{array}{c}5(23.8) \\
16(76.2)\end{array}$ & $\begin{array}{l}30(37.5) \\
50(62.5)\end{array}$ & 0.49 \\
\hline
\end{tabular}

In established RA, thirty seven $(46.3 \%)$ had diet restriction; while the remaining forty three $(53.8 \%)$ did not. A majority of them $(72.5 \%)$ did not feel any influence of diet on their joint symptoms while change in their symptoms in response to some dietary habits was observed in twenty two patients $(27.5 \%)$. The results are summarised in Table 3.

\section{Diet restrictors versus non restrictors}

There were a total of 44 patients who restricted their diet while 57 of them have been not on any kind of diet restriction for arthritis.

Of the diet restrictors majority was female (81.8\%); majority of them $(84.1 \%)$ had established disease more than 6 months; $50 \%$ had been exposed to alternative medicine. The exposure to alternative form of medicine was slightly higher in diet restrictor as compared to non-restrictor groups $(p=0.06)$. A majority $(77.3 \%)$ of the diet restrictor group did not have any co-morbidities.

A significant association was observed between diet restriction and any difference/worsening of joint symptoms $(p<0.0001)$. Twenty of the 44 patients who restricted their diet (45.5\%) felt a difference in joint symptoms on exposure to particular diet while the remaining 24 patients $(54.5 \%)$ did not feel so. 52 out of 57 $(91.2 \%)$ non restrictors did not experience any influence of diet on their symptoms while $5(8.8 \%)$ felt a change in symptoms even though they did not restrict any dietary foods in particular. The results are summarised in Table 4.

\section{Discussion}

In this study we analysed the influence of diet on joint symptoms in a group of patients by a simple questionnaire.
The mean age of our study population was $48.33 \pm 11.74$ years which is in comparable with the RA study population worldwide. Although our study did not target on established disease alone, we had more number of patients with established disease by consecutive picking. The mean disease duration in the study group was $50.22 \pm 65.39$ months which is important because this gives enough time for the patients to test various foods and to arrive at a conclusion regarding the influence of diet on their disease pattern.

The percentage of patients with associated co-morbid diseases like diabetes and hypertension requiring dietary restriction was less in our study population making this observation more relevant.

Almost all the alternative form of therapies mandates a specific dietary restriction. In our study, 50\% of dietary restrictors had alternative therapy exposure previously; although this association is not statistically significant which indicates that alternative medicine exposure does not influence the dietary patterns for our study population.

Patients who observed any changes in the joint symptoms on exposure to a particular diet adapt dietary restriction and we observe this association as statistically significant in our study $(p<0.0001)$. This emphasise the influence of diet on the disease activity as noted in other studies. 20 out of the 44 and 52 out of 57 patients in either groups were rightly deciding what to eat and what not to eat.

When we searched for similar studies, we could find one such questionnaire based study [27] which assessed diet and disease symptoms in rheumatic diseases. The study included a total of 742 patients which consisted of 290 patients with RA; 51 with Juvenile Rheumatoid arthritis, 87 with Ankylosing spondylitis, 51 with psoriatic arthropathy, 65 with primary fibromyalgia and 34 with osteoarthritis. The median disease duration of RA patients in this study was 11 months (0-55) which is shorter than our present study $(50.22 \pm 65.39$ months $)$. One third of

Table 4. Comparison of characteristics by diet restriction for arthritis: Reported as number within parenthesis percentages; $p$ value using chisquare test; * - $p$ value using independent t test.

\begin{tabular}{|c|c|c|c|}
\hline & \multicolumn{2}{|c|}{ Diet Restriction for Arthritis } & \multirow[b]{2}{*}{$P$ value } \\
\hline & $\begin{array}{l}\text { Yes } \\
n-44\end{array}$ & $\begin{array}{c}\text { No } \\
\mathrm{n}-57\end{array}$ & \\
\hline Age in years & $49.9 \pm 11.3$ & $47.1 \pm 11.9$ & $0.22^{*}$ \\
\hline $\begin{array}{l}\text { Sex } \\
\text { Female } \\
\text { male }\end{array}$ & $\begin{array}{c}36(81.8) \\
8(18.2)\end{array}$ & $\begin{array}{c}49(86.0) \\
8(14.0)\end{array}$ & 0.57 \\
\hline $\begin{array}{l}\text { Duration of disease } \\
\quad \leq 6 \text { months } \\
>6 \text { months }\end{array}$ & $\begin{array}{c}7(15.9) \\
37(84.1)\end{array}$ & $\begin{array}{l}14(24.6) \\
43(75.4)\end{array}$ & 0.28 \\
\hline $\begin{array}{c}\text { Alternative Medications } \\
\text { Yes } \\
\text { No }\end{array}$ & $\begin{array}{l}22(50.0) \\
22(50.0)\end{array}$ & $\begin{array}{l}18(31.6) \\
39(68.4)\end{array}$ & 0.06 \\
\hline $\begin{array}{c}\text { Co morbid conditions } \\
\text { Yes } \\
\text { No }\end{array}$ & $\begin{array}{l}10(22.7) \\
34(77.3)\end{array}$ & $\begin{array}{c}8(14.0) \\
49(86.0)\end{array}$ & 0.26 \\
\hline $\begin{array}{c}\text { Any difference in joint pains } \\
\text { Yes } \\
\text { No }\end{array}$ & $\begin{array}{l}20(45.5) \\
24(54.5)\end{array}$ & $\begin{array}{c}5(8.8) \\
52(91.2)\end{array}$ & $<0.0001$ \\
\hline $\begin{array}{l}\text { Type of food } \\
\text { Veg } \\
\text { Mixed }\end{array}$ & $\begin{array}{l}19(43.2) \\
25(56.8)\end{array}$ & $\begin{array}{l}16(28.0) \\
41(72.0)\end{array}$ & 0.15 \\
\hline
\end{tabular}


Rheumatoid arthritis patients reported worsening of symptoms after a particular food intake which is comparable to our observation (one fourth). But there was not any definite answer for the same.

Understanding the association between diet and RA disease activity, numerous studies had been conducted in various parts of the world to ascertain whether dietary manipulation is rewarding in the management of RA patients in terms of improvement in joint pain, stiffness and physical function. Dietary intervention measures followed in various studies include fasting followed by vegetarian diet $[14,28]$, vegan diet $[16,29]$, elemental diet [30,31], Mediterranean diet [32,33], Elimination diet [34] and the results were compared with those put on ordinary diet but the results of these studies were variable.

Hagen et al. [35] did a systemic review of all these dietary intervention studies which included 14 randomised controlled trials, 1 case control study with a total of 837 patients and concluded that the effect of various forms of dietary manipulation on RA patients is uncertain. It was also noted that there was a high risk of dropout rates and weight loss in those subjected to dietary manipulation or restriction which can cause adverse potential effects.

Our study is one of its kinds which assessed the real life situation of patients with RA and their ever burning question of the influence of diet on the disease. It is easier to assess the role of drugs in the disease management and various trials can be formulated for the same while it is tough to assess the role of dietary factors and its influence on the disease course. Since RA as such has a variable course and each patient behaves in a different manner with periods of spontaneous remissions and exacerbations. Not all patients with RA are capable of sticking to a particular diet regimen. Most of the real life patients are in the lower to middle socio-economic class and following a special diet pattern will only add to the financial burden for their families.

We did make out from our study that the patients are the best judges of their symptoms and the influence of diet on their disease pattern. Our advice for the patients is to decide on their own basis whether or not to restrict a particular food item based on their symptoms instead of giving a dietary pattern for them.

So, till we have convincing data regarding the benefits of dietary manipulation in Rheumatoid arthritis patients, we encourage them to have a healthy, balanced diet with individual modifications in their diet pattern based on their own judgement regarding the influence of diet on their joint related symptoms.

\section{Limitations of our Study}

This is a cross-sectional study; we have not objectively assessed the influence of diet on the disease activity; instead our study was based on the assessment on arthritis related symptoms by patients themselves.

\section{Funding}

We have not received any funds from any agencies or sponsors.

\section{Competing and Conflicting Interest}

The authors disclose no conflicting or competing interest.

\section{Acknowledgements}

We acknowledge the work done by Biostatistician Mrs. Sumithra Selvam for her statistical assistance.

\section{References}

1. Silman A, MacGregor A, Thomson W, et al. Twin concordance rates for rheumatoid arthritis: results from a nationwide study. Br J Rheumatol. 1993;32:903-7.

2. Heliovaara M, Aho K, Aromaa A, et al. Smoking and risk of rheumatoid arthritis. J Rheumatol. 1993;20:1830-5.

3. Voigt LF, Koepsell TD, Nelson JL, et al. Smoking, obesity, alcohol consumption, and the risk of rheumatoid arthritis. Epidemiology. 1994;5:525-32.

4. Symmons DP, Bankhead CR, Harrison BJ, et al. Blood transfusion, smoking, and obesity as risk factors for the development of rheumatoid arthritis: results from a primary care-based incident case-control study in Norfolk, England. Arthritis Rheum. 1997;40:1955-61.

5. Hutchinson D, Shepstone L, Moots R, et al. Heavy cigarette smoking is strongly associated with rheumatoid arthritis (RA), particularly in patients without a family history of RA. Ann Rheum Dis. 2001;60:223-7.

6. Choi HK: Dietary risk factors for rheumatic diseases. Curr Opin Rheumatol. 2005;17:141-6.

7. Beri D, Malaviya AN, Shandilya R, et al. Effect of dietary restrictions on disease activity in rheumatoid arthritis. An Rheum Dis. 1988;47:69-72.

8. Vaahtovuo J, Munukka E, Korkeamäki M, et al. Fecal microbiota in early rheumatoid arthritis. J Rheumatol. 2008;35:1500-5.

9. Toivanen P. Normal intestinal micro biota in the etiopathogenesis of rheumatoid arthritis. Ann Rheum Dis. 2003;62:807-11.

10. Scher JU, Sczesnak A, Longman RS, et al. Expansion of intestinal Prevotella copri correlates with enhanced susceptibility to arthritis. Elife. 2013;2:e01202.

11. Buchanan WW, Laurent RM. Rheumatoid arthritis: an example of ecological succession? Can Bull Med Hist. 1990;7:77-91.

12. Pattison DJ, Symmons DP, Lunt M, et al. Dietary risk factors for the development of inflammatory polyarthritis: evidence for a role of high level of red meat consumption. Arthritis Rheum. 2004;50:3804-12.

13. Skoldstam L. Fasting and vegan diet in rheumatoid arthritis. Scand J Rheumatol. 1986;15:219-21.

14. Kjeldsen-Kragh J, Haugen M, Borchgrevink CF, et al. Controlled trial of fasting and one year vegetarian diet in rheumatoid arthritis. Lancet. 1991;338:899-902.

15. Kjeldsen-Kragh J, Haugen M, Forre O, et al. Vegetarian diet for patients with rheumatoid arthritis: can the clinical effects be explained by the psychological characteristics of the patients? Br J Rheumatol. 1994;33:569-75. 
16. Nenonen MT, Helve TA, Rauma AL, et al. Uncooked, lactobacilli-rich, vegan food and rheumatoid arthritis. Br J Rheumatol. 1998;37:274-81.

17. Grant WB. The role of meat in the expression of rheumatoid arthritis. Br J Nutr. 2000;84:589-95.

18. Linos A, Kaklamanis E, Kontomerkos A, et al. The effect of olive oil and fish consumption on rheumatoid arthritis: a case control study. Scand J Rheumatol. 1991;20:419-26.

19. Shapiro JA, Koepsell TD, Voigt LF, et al. Diet and rheumatoid arthritis in women: a possible protective effect of fish consumption. Epidemiology. 1996;7:256-63.

20. Linos A, Kaklamani VG, Kaklamani E, et al. Dietary factors in relation to rheumatoid arthritis: a role for olive oil and cooked vegetables? Am J Clin Nutr. 1999;70:1077-82.

21. Cerhan JR, Saag KG, Merlino LA, et al. Mikuls TR, Criswell LA. Antioxidant micronutrients and risk of rheumatoid arthritis in a cohort of older women. Am J Epidemiol. 2003;157:345-54.

22. Bendich A, Olson JA. Biological actions of carotenoids. FASEB J. 1989;3:1927-32.

23. Heliovaara M, Aho K, Knekt P, et al. Coffee consumption, rheumatoid factor, and the risk of rheumatoid arthritis. Ann Rheum Dis. 2000;59:631-5.

24. Mikuls TR, Cerhan JR, Criswell LA, et al. Coffee, tea, and caffeine consumption and risk of rheumatoid arthritis: results from the Iowa Women's Health Study. Arthritis Rheum. 2002;46:83-91.

25. Proudman SM, James MJ, Spargo LD, et al. Fish oil in recent onset rheumatoid arthritis: a randomised, doubleblind controlled trial within algorithm-based drug use. Ann Rheum Dis. 2015;74:89-95.

26. Benito-Garcia E, Feskanich D, Hu FB, et al. Protein, iron, and meat consumption and risk for rheumatoid arthritis: a prospective cohort study. Arthritis Res Ther. 2007;9:R16.
27. Haugen M, Kjeldsen-Kragh J, Nordvåg BY, et al. Diet and disease symptoms in rheumatic diseases-results of a questionnaire based survey. Clin Rheumatol. 1991;10:401-7.

28. Sköldstam L, Larsson L, Lindström FD. Effects of fasting and lactovegetarian diet on rheumatoid arthritis. Scandinavian J Rheumatol. 1979;8:249-55.

29. Hafström I, Ringertz B, Spångberg A, et al. A vegan diet free of gluten improves the signs and symptoms of rheumatoid arthritis: the effects on arthritis correlate with a reduction in antibodies to food antigens. Rheumatology. 2001;40:1175-9.

30. Holst-Jensen SE, Pfeiffer-Jensen M, Monsrud M, et al. Treatment of rheumatoid arthritis with a peptide diet. A randomized, controlled trial. Scandinavian J Rheumatol. 1998;27:329-36.

31. Kavanagh R, Workman E, Nash P, et al. The effects of elemental diet and subsequent food reintroduction on rheumatoid arthritis. British J Rheumatology. 1995;34:270-3.

32. McKellar G, Morrison E, McEntegart A, et al. A pilot study of a Mediterranean type diet intervention in female patients with rheumatoid arthritis living in areas of social deprivation in Glasgow. Annals of the Rheumatic Diseases. 2007;66:139-43.

33. Sköldstam L, Hagfors L, Johansson G. An experimental study of Medieterranean diet intervention for patients with rheumatoid arthritis. Annals of the Rheumatic Diseases. 2003;62:208-14.

34. Darlington LG, Ramsey NW, Mansfield JR. Placebo controlled, blind study of dietary manipulation therapy in rheumatoid arthritis. Lancet. 1986; February:236-8.

35. Hagen KB, Byfuglien MG, Falzon L, et al. Dietary interventions for rheumatoid arthritis. Cochrane Database Syst Rev. 2009; 1:CD006400.

\section{*Correspondence to:}

Nagaprabu VN

DNB Rheumatology

Sakthi Rheumatology Centre Private Ltd. Coimbatore, Tamilnadu

India

E-mail: nagaprabu1@gmail.com 